\title{
Bacterial Parasite of a Cladoceran: Morphology, Development In Vivo, and Taxonomic Relationships with Pasteuria ramosa Metchnikoff 1888
}

\author{
R. M. SAYRE, J. R. ADAMS, AND W. P. WERGIN \\ Plant Protection Institute, Science and Education Administration, Agricultural Research, United States \\ Department of Agriculture, Beltsville, Maryland 20705
}

\begin{abstract}
A parasite of the cladoceran Moina rectirostris Leydig 1860 found near Beltsville, Md. and designated CPB was successfully propagated for morphological and ultrastructural studies by infecting laboratory-reared hosts. An ultrastructural examination of vegetative cells indicated that the parasite was procaryotic. The morphology of CPB was nearly identical to that of Pasteuria ramosa Metchnikoff 1888. Consequently, CPB was considered to be an organism like $P$. ramosa. An electron microscopic study of CPB provided no evidence of longitudinal fission, a concept which had been proposed for $P$. ramosa by Metchnikoff, but supported much of Metchnikoff's original description for P. ramosa. For example, CPB was a parasite of a cladoceran. Primary colonies were cauliflower-like. Daughter colonies were formed by fragmentation of mother colonies and produced quartets, doublets, and single sporangia. A sporangium consisted of a conical stem, a swollen middle cell, and an endogenous spore.
\end{abstract}

In a previous study (11), a cladoceran parasite infecting the water flea Moina rectirostris Leydig 1860 was found near Beltsville, Md. The parasite, designated $\mathrm{CPB}$, appeared to be morphologically similar to the bacterium Pasteuria ramosa Metchnikoff 1888 (8) (description emended by Hirsch 1971 [7]) and closely resembled a bacterial spore parasite of nematodes (10). However, additional morphological and physiological characterization was needed before CPB could be properly identified. In this study, our objectives were (i) to develop a means of propagating CPB by inoculating large numbers of laboratory-reared $M$. rectirostris with the parasite, (ii) to follow the development of CPB in its host with light and electron microscopy, (iii) to study the effect of environmental factors influencing the parasite growth, and (iv) to compare CPB with previously described, apparently similar organisms.

\section{MATERIALS AND METHODS}

Preliminary attempts to culture $\mathrm{CPB}$ in vitro on different bacteriological media failed. Therefore, we undertook in vivo cultivation of the organism. Large numbers of laboratory-reared cladocerans $(M$. rect $i$ rostris) were used as susceptible hosts for the bacterium. The food sources for laboratory rearing of the cladocerans included: (i) dilute bacterial infusions and dilute suspensions of yeast cells $(1,3,4,14)$; (ii) a mixture of finely ground alfalfa meal, Trout Chow, and Tetra-Min suspended in water (this medium is cur- rently used at the Environmental Protection Agency, Animal Laboratory, Beltsville, Md., for rearing Daphnia magna); and (iii) algal cells, predominately Scenedesmus sp., grown in greenhouse aquaria and currently used by the Pesticide Degradation Laboratory, Beltsville, Md., for rearing D. magna. Culture dishes ( 60 by $100 \mathrm{~mm}$ ) containing $150 \mathrm{ml}$ of pond water were used as aquaria for about 200 to 500 cladocerans. The use of algal cells, which were added daily at the rate of approximately $3 \times 10^{6}$ cells to each aquarium, was found to be most successful. This system tolerated the errors that are inevitably made in feeding cladocerans over a period of several days. With the other two food sources, cladoceran populations quickly died if they were overfed with bacteria or if organic matter accumulated to levels that supported luxuriant bacterial growth.

Cells of CPB used to inoculate healthy cladocerans were obtained from two sources: (i) sediments from the bottoms of aquaria where the bodies of parasitized cladocerans accumulated, and (ii) living parasitized cladocerans from cultures. The sediments were air dried, powdered by means of a mortar and pestle, thoroughly mixed, and then stored at room temperature.

The effects of heating and storage on the viability of CPB spores were studied by addition of heated or stored sediment or sporangia to cultures of cladocerans. The sporangia were obtained by crushing living parasitized cladocerans that were taken from cultures. The liberated sporangia were counted in a blood cell chamber and diluted to a known concentration before use.

For study of the parasite development within the host, 100 to 200 cladocerans were crowded into a 
volume of $10 \mathrm{ml}$ of water to increase the chances of infection. Then, $0.05 \mathrm{~g}$ of the air-dried sediments was added and the mixture was shaken. The cladocerans were left in this small volume of inoculum for $3 \mathrm{~h}$ to acquire the parasite before they were returned to 140 $\mathrm{ml}$ of pond water in a rearing aquarium. The aquarium was then placed under a bank of two cool white fluorescent tubes and two incandescent bulbs that provided an 18-h-light-6-h-dark cycle. At the water surface, the irradiation from the light source measured $420 \mu \mathrm{E} \mathrm{m}^{-2} \mathrm{~s}^{-1}$ on a type LI-185 meter, Lambda Instruments, Inc., equipped with a quantum sensor. To study the effects of different water temperatures on the development of the parasite in cladocerans, culture dishes were placed on two microscope slide warmers, one regulated to $25^{\circ} \mathrm{C}$ and the other regulated to $31^{\circ} \mathrm{C}$. Other dishes were left at room temperature or at $21^{\circ} \mathrm{C}$. The development of the parasite within the hemocoele of living cladocerans was followed microscopically for 16 days. Cladocerans were filtered from the aquarium onto a 200 -mesh screen and then backwashed from the screen into a $150-\mathrm{mm}$ plastic petri dish with a counting grid. Water was withdrawn from the petri dish, leaving the cladocerans stranded and immobilized in a thin film of moisture in the counting dish. The dish was covered, and the cladocerans in each square were observed with a Nikon model $M$ inverted microscope equipped with a planachromat $42 \times$ objective with a working distance of 1.1 to $1.5 \mathrm{~mm}$. The cladoceran's hemocoele was observed for developing parasites. The smooth, transparent exoskeleton around the eye of the cladoceran allowed the best view of the developing endoparasites in the circulating hemolymph.

A culture of $P$. ramosa ATTC 27377 obtained from the American Type Culture Collection (ATCC) was grown on glass cover slips in vials of caulobacter liquid medium (5) and was morphologically compared with CPB by the use of light and scanning electron microscopy. Cover slips with adhering bacteria were cleaned on one surface and mounted on glass slides; the bacteria on the other surface were then observed with light microscopy. Additional cover slips with bacteria were placed in $3 \%$ glutaraldehyde for $1.5 \mathrm{~h}$, dehydrated in an ethanol series, and critical-point dried. The slips were then attached to stubs with Avery self-adhesive paper tacks, coated with gold palladium, and examined with a Hitachi HHS-2R scanning electron microscope operated at 15 or $20 \mathrm{kV}$. Sporangia of the CPB were also prepared for scanning electron microscopy. Parasitized females were crushed on stubs. The liberated sporangia were allowed to air-dry before coating and examination. Developmental stages of CPB observed in the hemolymph were photographed with a Zeiss Ultraphot II microscope equipped with phase and dark-field optics. Cladocerans that contained developing stages of the parasite were selected and fixed in $3 \%$ glutaraldehyde, with an osmolality of $0.468 \mathrm{osmol} /$ $\mathrm{kg}$, for $24 \mathrm{~h}$ and then washed in six changes of phosphate buffer over a period of $1 \mathrm{~h}$. The parasitized cladocerans were postfixed in $2 \%$ osmium tetroxide for $2 \mathrm{~h}$, dehydrated in an acetone series, and infiltrated with Spurr low-viscosity medium (12). Silver-gray sections of the infiltrated cladocerans were cut on a
L.K.B. Ultramicrotome III with a diamond knife. The sections were stained with uranyl acetate and lead citrate (9). Thin sections were viewed with a Philips 301 electron microscope operating at $60 \mathrm{kV}$ with a 20 $\mu \mathrm{m}$ aperture.

\section{RESULTS}

Light microscopy. The first stage in the development of CPB that was observed microscopically was the cauliflower-like mycelial growth in the hemocoele of a cladoceran. These growths were most numerous on the inner walls of the carapace (Fig. 1). The next detectable stage of the parasite consisted of quartets of sporangia. During this stage, the hemolymph around the cladoceran's eye appeared to be free of sporangia; however, quartets from the hemolymph frequently attached to the eye muscle fibers giving them a beaded appearance (Fig. 2 and 4). Later, when the hemolymph surrounding the eye became noticeably cloudy (Fig. 3 ), the predominant stage of the parasite consisted of double (Fig. 5) and single (Fig. 6) immature sporangia. At this stage, the cladoceran swam rapidly and its heartbeat appeared normal. During the final stage of the development of the parasite, the mature sporangia (Fig. 7) became so numerous that the eye and its muscle attachments were obscured; nevertheless, the heart continued to beat, and most cladocerans were capable of slow swimming. Parasitized adults, which also became filled with sporangia, appeared opaque, and usually had no young in their egg pouches. When these adults were crushed, each one yielded about $2 \times 10^{5}$ sporangia. The final stage of $\mathrm{CPB}$, liberated from dying adults, was a teardrop-shaped sporangium. When examined with phase microscopy, the anterior or wide end of the sporangium was highly refractile (Fig. 7).

Electron microscopy. Electron micrographs of the "cauliflower" stage of CPB revealed circular patterns of hyphal strands of an apparently actinomycete-like organism (Fig. 8 and 9). $\mathrm{Hy}$ phal strands were septate (Fig. 10 and 11). The width of hyphal cells measured from $0.67 \pm 0.06$ (average \pm 1 standard deviation) $\mu \mathrm{m}$. The hyphal wall, which was fairly homogeneous in density, measured 14.5 to $15 \mathrm{~nm}$ in thickness. Between the wall and the cell membrane was a space 8.7 to $9.0 \mathrm{~nm}$ wide. The thickness of the cell membrane measured $5.8 \mathrm{~nm}$ (Fig. 12). Mesosomes (circular membrane complexes) were often found associated with septa (Fig. 13).

Because of the continual fragmentation of hyphae, the single sporangial stage of CPB predominated in the hemolymph late in the life cycle of the adult cladoceran. The extensive 



FIg. 1-3. A bacterial parasite (CPB) in living M. rectirostris. (Fig. 1) Cauliflower-like growths (cg) of CPB attached to the inner walls of the carapace $(\times 2,800)$. (Fig. 2) Eye muscle attachment fibers $(f)$ partially covered with the immature sporangia (sp) of $C P B(\times 650)$. (Fig. 3) The anterior of the cladoceran showing the eye cavity filled with sporangia of $C P B(\times 350)$.

FIg. 4-7. Sporangial stages of a bacterial parasite in M. rectirostris $(\times 3,400)$. (Fig. 4) Quartet of sporangia. (Fig. 5) Doublet. (Fig. 6) Immature sporangium with a refractile spore and stem. (Fig. 7) Mature sporangium with a highly refractile endospore. 




FIG. 8-13. Electron micrographs of the vegetative stages of a bacterial parasite from $M$. rectirostris. (Fig. 8) Cross section of mycelium in hemocoele $(\times 5,320)$. (Fig. 9) Cross section of a fragmenting mycelium $(\times 11,500)$. (Fig. 10) Section through quartet of sporangia illustrating septa (s) and lighter nuclear areas (na) $(\times 34,000)$. (Fig. 11) Sections through a doublet, showing multiple septa (s) $(\times 18,000)$. (Fig. 12) Section showing a cell wall (cw), cell membrane (cm), and junction with a septum (×54,400). (Fig. 13) Mesosome (m) associated with a septum $(\times 34,000)$. 

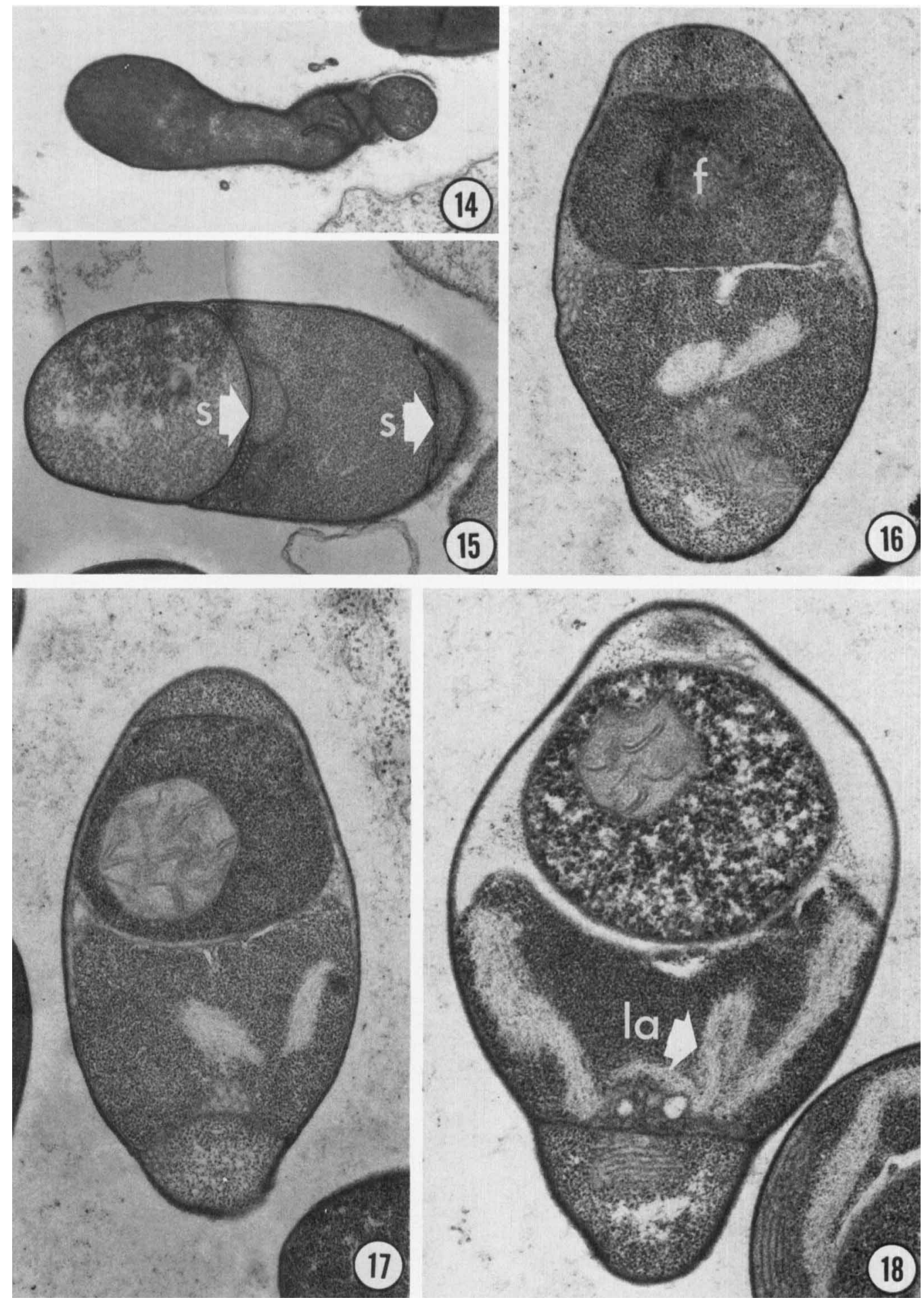

FIG. 14-18. Electron micrographs of the sporangial formation in a bacterial parasite of $M$. rectirostris. (Fig. 14) Expanding sporangium before spore formation $(\times 19,880)$. (Fig. 15) Septa (s) divides the immature sporangia into three parts $(\times 21,000)$. (Fig. 16) Forespore $(f)$ condensing from the anterior cytoplast of the sporangium $(\times 28,140)$. (Fig. 17) Later stage in spore formation showing the beginning of cortex and spore walls (×28,140). (Fig. 18) Light areas (la) of the sporangium show possible precursors of spore appendages on the mature spore $(\times 32,440)$. 
vegetative mycelium was no longer present, and only a few undeveloped but enlarged hyphal fragments persisted. Spore formation began soon after the terminal or distal cells of the mycelium enlarged (Fig. 14). The septum (Fig. 15) that was laid down within the sporangium separated the upper one-third of the sporangium, which became occupied by the forespore (Fig. 16), from the lower portion of the sporangium. The granular anterior portion of the sporangium then condensed into an electron-dense, opaque forespore (Fig. 17) measuring $1.35 \pm 0.086 \mu \mathrm{m}$ in diameter (Fig. 18). Later, this spore comprised a multilayered wall, a very electron-dense cortex, and central cytoplasm, which contained numerous doubled fibrillar strands (Fig. 19).

During spore formation, structural changes also occurred in the lower portions of the sporangium. After formation of the anterior septum, the median section remained structurally unchanged except for an occasional mesosome. The presence of numerous ribosomes resulted in a granular appearance (Fig. 15). An additional septum formed lower in the sporangium, separating it from a conical stem. Condensation of the forespore was accompanied by the appearance of light areas in the median parasporal section (Fig. 17 and 18). These areas appeared to expand and attach laterally to the multilayered spore wall to form inverted "wings" on the spore (Fig. $19)$.

Temperature requirements and host specificity. The influence of water temperature on the occurrence of CPB in $M$. rectirostris in the field was observed over a 3-year period. The parasite was not found until the surface water temperature in the pond reached $26^{\circ} \mathrm{C}$ or more. This occurred about mid-July in the Beltsville area. The apparent temperature requirement was confirmed in laboratory tests where water in the aquaria was held at constant temperatures: the parasite was found in 6 and 3 days at 26 and $31^{\circ} \mathrm{C}$, respectively (Fig. 20), but it was not isolated at $21^{\circ} \mathrm{C}$.

Air-dried CPB sporangia, which were stored for 6 months, were capable of infecting healthy populations of cladocerans. However, when airdried CPB-containing aquarium sediments were heated at 40,60 or $80^{\circ} \mathrm{C}$ on a block heater for 10 $\mathrm{min}$ and then added to cultures of healthy cladocerans, the parasites developed in cultures that were given sediments which were heated at 40 and $60^{\circ} \mathrm{C}$. Similarly, when sporangia taken from crushed, parasitized cladocerans were heated to 40,60 , or $80^{\circ} \mathrm{C}$ for $10 \mathrm{~min}$ in glass capillaries and then added to healthy populations, development occurred in the control (unheated) sporangia and in those treated at $40^{\circ} \mathrm{C}$ but not in those heated at 60 or $80^{\circ} \mathrm{C}$.
Attempts to infect D. magna, a species closely related to $M$. rectirostris, failed. Neither the bottom sediments from aquaria nor spores from crushed parasitized $M$. rectirostris were able to infect D. magna.

Comparison with described species. Pasteuria ramosa ATCC 27377 was grown on glass cover slips in vials of caulobacter liquid medium (5). Light microscopy revealed quartets of bacterial cells (Fig. 21) that were similar in appearance to the quartets of sporangia of CPB (Fig. 22 ). Cells on other cover slips were examined with the scanning electron microscope and were found to possess holdfast structures (Fig. 23). Scanning electron microscopy of CPB sporangia revealed segments of the sporangium that consisted of an anterior cap, a swollen middle portion, and a conical stem (Fig. 24).

\section{DISCUSSION}

A comparison of Metchnikoff's original drawings of $P$. ramosa (Fig. 25, 26, 27, and 28) and Weiser's original drawings of Lymphocystidium daphniae Weiser 1943 (Fig. 29, 30, 31, and 32) with electron micrographs of CPB (Fig. 33, 34, 35 , and 36 ) revealed striking similarities in morphology. The morphology and ultrastructure of the vegetative and sporangial stages of $C P B$ are similar to those in other bacterial species with endogenous spore formation. The first observed stage of the parasite, which consisted of small mycelial growths clinging to the inner walls of the carapace, is composed of cells that appear to be procaryotic. The ultrastructure of vegetative cells and the formation of septations are typical of those features in bacteria. Sporulation is also typical of bacteria. Endospores are formed singly within the sporangium. At maturity, multilayered spore coats and a cortex develop. The spore is resistant to desiccation. However, the air-dried spores are only slightly resistant to high temperatures. Except for this very limited heat resistance, the remaining characteristics of CPB spores are similar to those used by Cross (2) to classify bacterial groups that include genera from the Actinomycetales, which are true endogenous sporeformers. Consequently, we have tentatively concluded that $\mathrm{CPB}$ is a true endogenous sporeformer and that, because of its mycelial vegetative stage, it may be a member of the order Actinomycetales.

In addition to their morphological similarities, the three organisms exhibit a common type of spore formation and an inability to grow in defined media. Metchnikoff (8) and Weiser (15) recognized the resistance of mature endospores to staining and the refractile quality of the mature sporangia; these features are also character- 




Fig. 19. Mature spore made up of multilayered spore walls (mw), cortex (c), and cytoplast with stranded inclusions (st). Septum (s) separates the stem from the middle cell. The function of fibrous spore wing (wi) appendages is not known $(\times 47,600)$. 
NUMBER OF $M$. RECTIROSTRIS AND THE PERCENT INCIDENCE OF C $P$ B

AT 26 AND $31^{\circ} \mathrm{C}$ AFTER INOCULATION WITH 500,000 SPORES

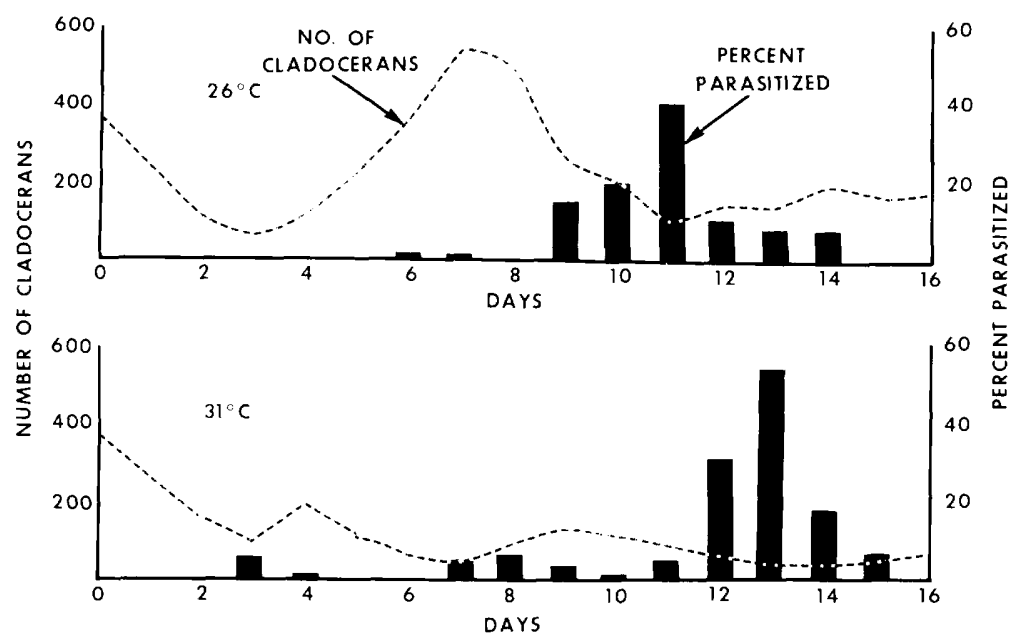

FIG. 20. Number of $M$. rectirostris per aquarium and the percent parasitized with bacterium $C P B$ after inoculation with 500,000 spores and incubation at 26 and $31^{\circ} \mathrm{C}$.
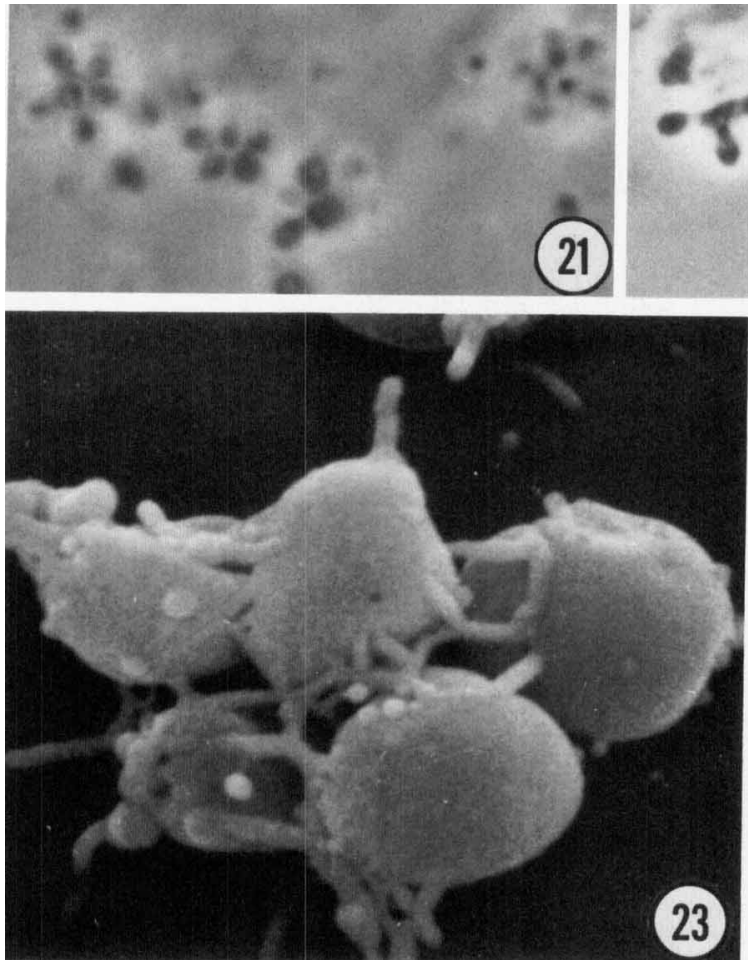

FIG. 21-24. The budding bacterium P. ramosa ATCC 27377 grown in vitro with cover slip as the inert substrate for attachment compared with CPB with light and scanning electron microscopy. (Fig. 21) Photomicrograph showing quartets of cells of P. ramosa ATCC 27377. (Fig. 22) Photomicrograph of CPB quartets of sporangia. (Fig. 23) Scanning electron micrograph showing a group of cells attached to a glass surface $(\times 25,000)$. (Fig. 24) Scanning electron micrograph of four sporangia of a bacterial parasite from $M$. rectirostris. External ridges mark boundaries of the spore (sp), the middle cell ( $\mathrm{mc}$ ), and stem (s) of a mature sporangium $(\times 10,000)$. 

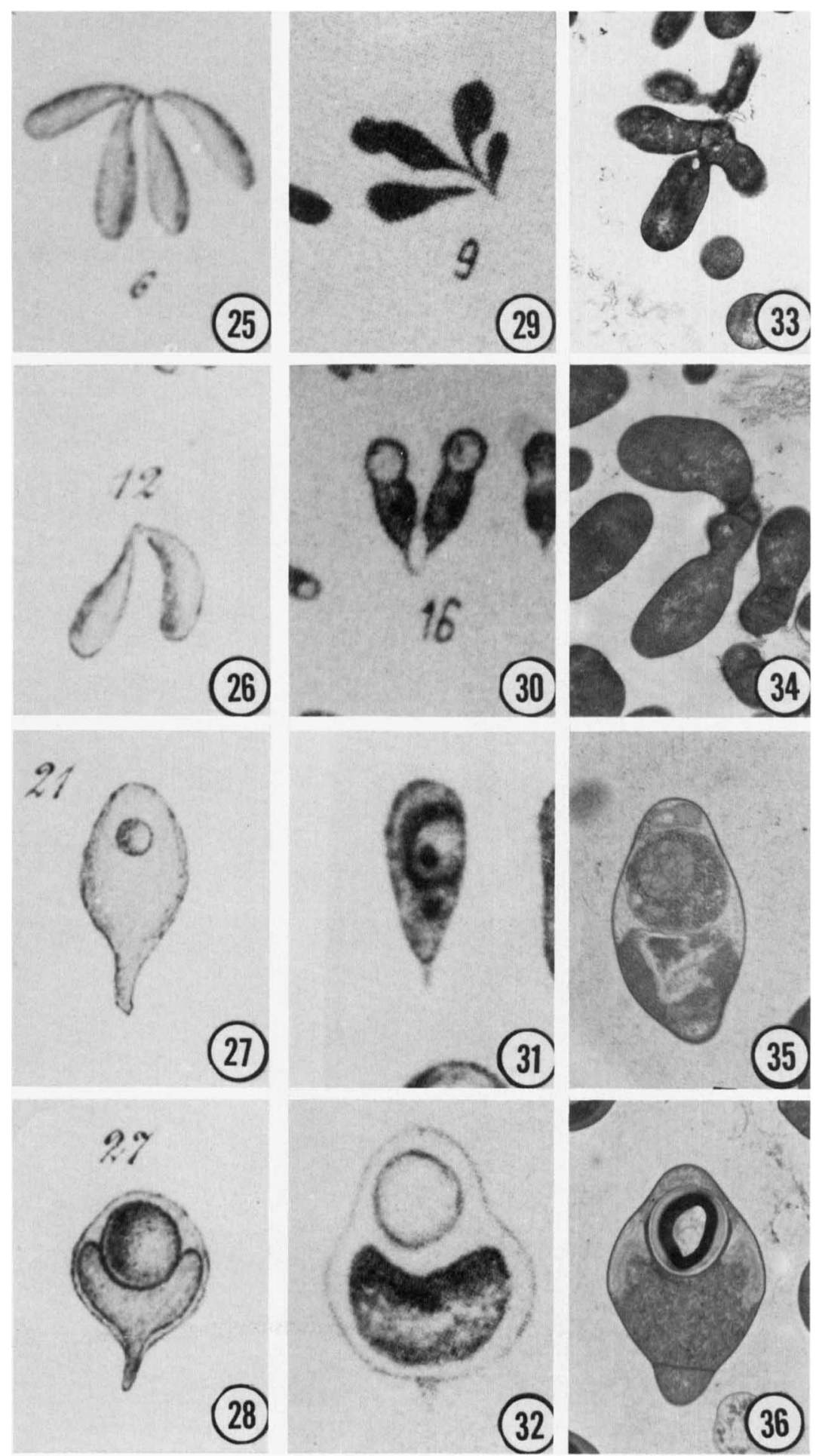

Fig. 25-36. The morphologies of $P$. ramosa, $L$. daphniae, and a bacterial parasite of $M$. rectirostris are compared. (Fig. 25 to 28) Quartet, doublet, immature sporangium, and mature sporangium of P. ramosa drawn by Metchnikoff (8). (Fig. 29 to 32) Life stages of L. daphniae as drawn by Weiser (15). (Fig. 33 to 36) Electron micrograph of the vegetative and sporangial developmental stages of $C P B$ found in $M$. rectirostris. 
istic of CPB. Both authors followed the development of the parasite in the host. Their illustrations of the various stages of the parasite parallel the developmental sequence that we found for CPB. Also, both these investigators and we have been unable to culture the cladoceran parasite on any of several common, defined media.

Metchnikoff (8) and Weiser (15) found their parasites in D. magna and $D$. pulex. The failure of CPB to infect D. magna suggests that their parasite differs from ours. However, this may be a minor physiological difference, reflecting the inability of one variant of an obligate parasite to reproduce in a host species closely related to its usual host.

One reason for our interest in CPB was Metchnikoff's (8) assertion that the fission of $P$. $r a$ mosa is an exception to the usual mode of bacterial division. He suggested that cells of $P$. ramosa undergo a longitudinal binary fission giving rise to a branched structure in which the two daughter cells remain attached at their tips (Fig. 25). He reasoned (i) that certain bacteria, such as sarcinas, may be looked upon as having the primitive characteristic of fission in three planes-longitudinal, transverse, and sagittal; (ii) that later-evolving rod-shaped organisms may have retained only longitudinal fission; and (iii) that the majority of bacteria now retain only transverse fission. He concluded that $P$. ramosa is a fairly primitive bacterium retaining longitudinal division.

Our results indicate that cleavage in CPB indeed occurs in three planes because this type of division is necessary to form spherical mycelial patterns (Fig. 8 and 9). However, we found no common plane of division, starting at the surface of the cauliflower-like growth and ending at its interior, that cleaves two daughter cells, as illustrated in Metchnikoff's original drawing no. 2 . The prominant bifurcations in the mycelium, which Metchnikoff also observed and which may have prompted his fission theory, were not products of atypical fission but were the distal or terminal cells of the mycelium undergoing rapid enlargement during formation of endogenous spores. These cells formed the sporangia.

Other investigators have been interested in reexamining the $P$. ramosa of Metchnikoff because of the questions raised by his theory of longitudinal binary fission. Henrici and Johnson (6), Hirsch (7), Zavarzin (16), and Staley (13) have investigated bacterial species similar in appearance to $P$. ramosa. One of these species so resembled $P$. ramosa that an amended description of this species was offered.
Currently, $P$. ramosa is characterized as a bacterium that reproduces by budding. The buds are motile and monotrichous. $P$. ramosa ATCC 27377 is indeed morphologically similar (Fig. 21) to CPB, but scanning electron microscopic examination reveals that CPB lacks holdfasts and has distinctive tripartite external morphology (Fig. 24), thereby making it distinctly different from the current concept of $P$. ramosa (Fig. 23). Because of similarities between CPB and the description offered by Metchnikoff, we feel that much of his original description and illustrations are still valid. Namely, primary colonies are "cauliflower-like"; daughter colonies are formed through fragmentation of mother colonies and produce "quartets," "doublets," and "single" sporangia; and the sporangium consists of a conical stem, an "enlarged middle section," and an endogenous spore.

\section{ACKNOWLEDGMENTS}

We thank Ron Yockum for his advice on culturing and identifying algae and on rearing and identifying cladocerans; John Resch, Alice Matthews, and Ted Wilcox for their technical assistance; and in particular R. E. Davis for calling our attention to the genus Pasteuria. Also, we thank J. Weiser for permission to use the original drawings in Fig. 33-36.

\section{REPRINT REQUESTS}

Address reprint requests to: Dr. R. M. Sayre, Plant Protection Institute, Science and Education Administration, Agricultural Research, U. S. Department of Agriculture, Beltsville, MD 20705.

\section{LITERA'TURE CITED}

1. Banta, A. M. 1921. A convenient culture medium for daphnids. Science 53:557.

2. Cross, T. 1970. Diversity of bacterial spores. J. Appl. Bacteriol. 33:95-102.

3. Galtsoff, P. S., F. E. Lutz, P. S. Welch, and J. G. Needham. 1937. Culture methods for invertebrate animals. Comstock Publishing Co., Inc., Ithaca, N.Y.

4. Grosvenor, G. H., and G. Smith. 1913. The life cycle of Moina rectirostris. Q. J. Microsc. Sci. 58:511-522.

5. Hatt, H. D. (ed.). 1978. Catalogue of strains I, 13th ed., p. 556. American Type Culture Collection, Rockville, Md.

6. Henrici, A. T., and D. E. Johnson. 1935. Studies of freshwater bacteria. II. Stalked bacteria, a new order of Schizomcyetes. J. Bacteriol. 30:61-93.

7. Hirsch, P. 1972. Re-evaluation of Pasteuria ramosa Metchnikoff 1888, a bacterium pathogenic for Daphnia species. Int. J. Syst. Bacteriol. 22:112-116.

8. Metchnikoff, M. E. 1888. Pasteuria ramosa, un représentant des bactéries à division longitudinale. Ann. Inst. Pasteur Paris 2:165-170.

9. Reynolds, E. S. 1963. The use of lead citrate at high $\mathrm{pH}$ as an electron opaque stain in electron microscopy. J. Cell. Biol. 17:208-212.

10. Sayre, R. M., and W.P. Wergin. 1977. Bacterial parasite of a plant nematode: morphology and ultrastructure. J. Bacteriol. 129:1091-1101.

11. Sayre, R. M., W. P. Wergin, and R. E. Davis. 1977 Occurrence in Moina rectirostris (Cladocera:Daphni- 
dae) of a parasite morphologically similar to Pasteuria ramosa (Metchnikoff, 1888). Can. J. Microbiol. 23: 1573-1579.

12. Spurr, A. 1969. A low-viscosity epoxy resin embedding medium for electron microscopy. J. Ultrastruct. Res. 26:31-43.

13. Staley, J. T. 1973. Budding bacteria of the PasteuriaBlastobacter group. Can. J. Microbiol. 19:609-614.
14. Stuart, C. A., M. McPherson, and H. J. Cooper. 1931. Studies on bacteriologically sterile Moina macrocopa and their food requirements. Physiol. Zool. 4:87-100.

15. Weiser, J. 1943. Beiträge zur Entwicklungsgeschichte von Dermocystidium daphniae Jirovec. Zool. Anz. 142:200205.

16. Zavarzin, G. A. 1961. Budding bacteria. Mikrobiologiya 30:952-975. (English translation) 30:774-791. 